\title{
COMUNICAÇÃO
}

\section{AN UNUSUAL RELAPSING CASE OF SKIN LEISHMANIASIS}

\author{
E.M. Netto, P.D. Marsden and E.M. Carvalho
}

We have been working in an endemic area of Leishmania viannia braziliensis (Lvb) transmission for 15 years at Três Braços in the interior of Bahia, Brazil. After attending approximately 1,000 patients we saw an exceptional case of relapsing cutaneous infection we would like to report here.

LTB 131, a 12 year old boy, came to the clinic with a typical leishmania ulcer on his right leg $(20 \mathrm{~mm}$ in diameter with a raised rolled edge) present for 6 months. Neither giemsa stained smears nor hamster inoculation showed evidence of parasites. Histology was compatible with the clinical diagnosis. The leishmanin test (using a $30 \mu \mathrm{g}$ dose of protein) was negative in 1980,1981 , twice in 1983 (a dose of $90 \mu \mathrm{g}$ on one occasion), 1985 and 1986. Low level titres of antileishmanial antibody $(1 / 20-1 / 64)$ were recorded by indirect immunofluorescent test on four occasions during 1980-1982. In 1980 when first seen he was advised to take $28 \mathrm{mg} \mathrm{Sb} / \mathrm{kg} /$ day of glucantime for 15 days with $10 \mathrm{mg} / \mathrm{kg}$ of nifurtimox for 30 days - a formulation under trial at the time. Actually he only took 9 days treatment with the two drugs and then defaulted. However his ulcer closed 4 months later.

In 1981 he developed a $10-15 \mathrm{~mm}$ ulcer on the left leg.A relapse was doubted, no treatment given and the ulcer healed spontaneously within a month. In 1982 he was seen twice with no signs of activity. In January 1983 the scar was infiltrated and surrounded by erythema ( 21 by $20 \mathrm{~mm}$ ). Relapse was considered but no investigations done and a 10 day course of glucantime $(18 \mathrm{mg} \mathrm{Sb} / \mathrm{kg})$ given. Within a month after treatment the reaction subsided and a further examination in October was unremarkable. The patient was not seen in 1984 but in February 1985 the left leg scar was the site of fresh ulceration ( 30 by $25 \mathrm{~mm}$ ). Glucantime was in short supply and only $9 \mathrm{mg} \mathrm{Sb} / \mathrm{kg}$ was given but even with such a low dose closure was noted in May 1985. In January 19863 ulcers were present in the site

Núcleo de Medicina Tropical e Nutrição, Universidade de Brasilia, Brasília, DF, Brasil.

Laboratório de Imunologia, Hospital Prof. Edgard Santos, Universidade Federal da Bahia, Salvador, BA, Brasil.

Recebido para publicação em 27/03/90. of the old scar on the left leg and the inguinal glands were enlarged. Glucantime $18 \mathrm{mg} \mathrm{Sb} / \mathrm{kg}$ for 30 days was begun. A biopsy showed signs of activity of his leishmanial granuloma but no parasites were isolated by culture or hamster inoculation. At that time IFA titre is positive at a dilution of $1 / 40$. His fourth relapse occurred in January 1987 with infiltration in the edge of the same site. Serology were negative and examination of the nose, mouth, throat and larynx were normal. Glucantime $17 \mathrm{mg} \mathrm{Sb} / \mathrm{kg}$ for 20 days was prescribed with a favourable result. In February 1990 the scars were firmly healed with no evidence of activity.

We recorded here our only patient with multiple skin relapses who always had a negative leishmaniasis skin test although skin biopsy findings and serology were compatible with the diagnosis of cutaneous leishmaniasis and he always responded well to pentavalent antimonial treatment. Parasite isolation was not possible but this is frequent with Lvb. We have recently reported our incidence of cutaneous relapses over a ten year period ${ }^{2}$. The persistently negative leishmanin skin test with reliable antigens indicated we should study his cellular immune response to leishmanial antigens and a positive lymproliferative response to Leishmania mexicana antigen was observed using techniques already described ${ }^{1}$. Evidently however this was not sufficient to produce a positive Montenegro reaction.

\section{REFERENCES}

1. Carvalho EM, Johnson WD, Barreto AC, Marsden PD, Costa JML, Reed S, Rocha H. Cell mediated immunity in American cutaneous and mucosal leishmaniasis. Journal of Immunology 135:4144-4148, 1985.

2. Netto EM, Marsden PD, LLanos-Cuentas EA, Costa JML, Cuba CC, Barreto AC, Badaró R, Johnson WD, Jones TC. Long-term follow-up patients with Leishmania (Viannia) braziliensis infection and treated with glucantime. Transactions of the Royal Society of Tropical Medicine and Hygiene 84:367-370, 1990. 